\title{
The Potential of Small Grains Crops in Enhancing Biofortification Breeding Strategies for Human Health Benefit
}

\author{
Tatyana V. Shelenga ${ }^{1}{ }^{\mathbb{D}}$, Yulia A. Kerv ${ }^{1}$, Irina N. Perchuk ${ }^{1}{ }^{\circledR}$, Alla E. Solovyeva ${ }^{1, *}$, Elena K. Khlestkina ${ }^{1}{ }^{\circledR}$, \\ Igor G. Loskutov ${ }^{1,2}$ and Alexey V. Konarev ${ }^{1}$
}

1 Directorate, Department of Biochemistry and Molecular Biology, Department of Genetic Resources of Oats, Rye and Barley, Federal Research Center N.I. Vavilov All-Russian Institute of Plant Genetic Resources (VIR) Ministry of Science and Higher Education, 190000 St Petersburg, Russia; tatianashelenga@yandex.ru (T.V.S.); kerv@mail.ru (Y.A.K.); i.perchuk@vir.nw.ru (I.N.P.); director@vir.nw.ru (E.K.K.); i.loskutov@vir.nw.ru (I.G.L.); a.konarev@vir.nw.ru (A.V.K.)

2 Department of Agrochemistry, Faculty of Biology, St. Petersburg State University, Ministry of Science and Higher Education, 199034 St Petersburg, Russia

* Correspondence: alsol64@yandex.ru; Tel.: +7-812-314-77-27

\section{check for} updates

Citation: Shelenga, T.V.; Kerv, Y.A.; Perchuk, I.N.; Solovyeva, A.E.; Khlestkina, E.K.; Loskutov, I.G.; Konarev, A.V. The Potential of Small Grains Crops in Enhancing Biofortification Breeding Strategies for Human Health Benefit. Agronomy 2021, 11, 1420. https://doi.org/ 10.3390/agronomy11071420

Academic Editor:

Maria Grazia Melilli

Received: 20 May 2021

Accepted: 12 July 2021

Published: 15 July 2021

Publisher's Note: MDPI stays neutral with regard to jurisdictional claims in published maps and institutional affiliations.

Copyright: (C) 2021 by the authors. Licensee MDPI, Basel, Switzerland. This article is an open access article distributed under the terms and conditions of the Creative Commons Attribution (CC BY) license (https:// creativecommons.org/licenses/by/ $4.0 /)$.

\begin{abstract}
Nutrition is a source of energy, and building material for the human organism. The quality of food has an effect on the quality of individual life. Minerals and vitamins participate in various catalytic and regulatory functions of the main metabolic processes: absorption, transport, redox and biosynthesis of organic compounds, genetic information transfer, etc. Regular consumption of dietary fibers like $\beta$-glucans and oat-specific phenolics, antioxidants, and avenanthramides, stimulate innate and acquired immunity, prevent cancer, obesity, reduce glucose, total cholesterol and triglyceride blood levels and regulate the expression of cholesterol-related genes. Thus, all those compounds are vitally important for the normal functional status of the human body. A deficiency in one or another essential nutrient causes disruptions in human metabolism, thus leading to serious illnesses. Plants are the main source of essential nutrients that are bioavailable for humans. One of the most popular groups of staple crops are the small grains crops (SGC), so these crops are most often used for biofortification purposes. Exploiting the potential of plant resources, biofortification is a long-term strategy, aimed at increasing the number of essential micro- and macronutrients in major food sources and ensuring their bioavailability. The most productive way to implement such strategy is the active use of the possibilities offered by collections of plant genetic resources, including SGC, concentrated in various countries of the world. The collections of plant resources contain both cultivated plants and their wild relatives that possess the required composition of micro- and macronutrients. A complex scientific approach to studying plant germplasm collections, together with agricultural practices (soil enrichment with fertilizers with a required composition), genetic biofortification (traditional breeding, marker-assisted selection or genetic engineering tactics), and their combinations will lead to the development of new biofortified cultivars and improvement of old ones, which can be used to solve the problems of unbalanced nutrition (malnutrition or hidden hunger) in different regions of the world.
\end{abstract}

Keywords: small grains crops; biofortification; plant genetic diversity; essential nutritive components; collection of plant genetic resources

\section{Introduction}

Nutrition is a crucial component in a full-fledged human life, a source of energy, and building material for the whole organism. The quality of food has an effect on the quality of life, including the ability to work and meet one's vital needs.

The United Nations General Assembly session, held on 1 April 2016, attended by both the WHO and FAO, emphasized the importance of healthy diets and food systems for global human health, naming an unhealthy diet and unwholesome food the main risks 
that increase disease development and death rate throughout the world. The period from 2016 through 2025 was announced the UN Decade of Action on Nutrition. The Rome Declaration on Nutrition, adopted by the Assembly, proposed an integrated strategy to eradicate hunger and end all forms of malnutrition, including undernutrition, micronutrient deficiencies, and obesity on a global scale. It encompasses the entire food system: from the quality of the produced plant raw materials, through the ways of their processing, to the utilization of food production wastes. One of the tasks to be approached is maximizing the nutritional value of staple food crops under global climate change. The environmental security problem of the contemporary agricultural production (reduction of greenhouse gas emissions, waste utilization, etc.) was considered separately as an integral part of the set of factors that directly or indirectly (through food products) affect human health [1-5].

Even a sufficient calorie intake does not preclude the state of "hidden hunger" induced by deficiencies in individual nutrients. A solution to this problem may be found if everyone had the right of access to a sufficient amount of safe and wholesome food, which must not only fully meet the energy requirements of an organism, but also ensure its functional adequacy. The labor activity level among the capable population and warranted development prospects for the rising generations depend directly on the said components [4].

One of the vitally important groups of nutrients for all biological organisms are micronutrients because they participate in various catalytic and regulatory functions of metabolic processes: absorption, transport, redox and biosynthesis of organic compounds, genetic information transfer, etc. Some micronutrients are coenzymes involved in major biosynthetic processes: iron, copper, molybdenum, manganese, zinc, magnesium and cobalt. Each micronutrient has its own concentration range safe for the normal functional state of a living organism; its violation leads to pathological deviations in metabolic processes [6,7] (Table 1).

Table 1. The main nutrients for the normal functional state of the human body [8-11].

\begin{tabular}{cc}
\hline Nutrient & Recommended Daily Intake \\
\hline Selenium & $6-42 \mu \mathrm{g} / \mathrm{day}$ \\
Iodine & $90-200 \mu \mathrm{g} / \mathrm{day}$ \\
Iron & $4-65 \mathrm{mg} / \mathrm{day}$ \\
Zinc & $72-457 \mathrm{mg} / \mathrm{kg} \mathrm{body} \mathrm{weight/day}$ \\
Vitamin A & $300-1000 \mathrm{mg} / \mathrm{day}$ \\
Vitamin B1 & $180-400 \mu \mathrm{g} / \mathrm{day}$ \\
Vitamin B2 & $0,2-1.5 \mathrm{mg} / \mathrm{day}$ \\
Vitamin B6 & $0.3-1.6 \mathrm{mg} / \mathrm{day}$ \\
Vitamin C & $0.1-2 \mathrm{mg} / \mathrm{day}$ \\
Vitamin E & $25-70 \mathrm{mg} / \mathrm{day}$ \\
Folic acid & $7-10 \mathrm{mg} / \mathrm{day}$ \\
\hline
\end{tabular}

The main sources of micronutrients necessary for humans are plants $[1,3,12,13]$.

\subsection{Mineral Components}

Mineral components reach their highest concentrations in the plant tissue when dissolved ionic forms of elements convert into the solid mineral phase, and biogenic minerals (bioliths) are generated. Barrier-type micronutrient accumulation is characteristic of the reproductive plant organs (seed or fruit), the ones that most often have alimentary value for humans [14].

Iodine is present in the composition of thyroid hormones (thyroxine and triiodothyronine) that regulate basic growth and development processes in an organism. Functional significance of iodides partially coincides with that of Se, Fe and $\mathrm{Zn}$. Iodine deficiency is consequential in areas where fish and other seafood are unavailable to the population, which leads to goiter (swelling in the thyroid gland tissues in an attempt to compensate for iodine deficiency) or even cretinism, the extreme form of iodine deficiency syndrome. This 
problem is critical mostly for India, with its 50 million cases of goiter and over two million of cretinism $[3,13,15,16]$.

Iron is present in the oxygen transport systems of hemoglobin and myoglobin, and active sites of cytochromes responsible for energy metabolism in the human organism. Its deficiency can lead to chronic anemia and, consequently, to a disturbance of growth and development processes, which is especially hazardous for pregnant women and children. Clinical manifestations of iron deficiency are aggravated by the presence of accompanying illnesses (malaria, HIV, tuberculosis, etc.). About two billion people suffer worldwide from iron deficiency anemia $[1,3,13,15,16]$.

Zinc is trace elements, a cofactor for about 100 enzymes, and is incorporated in many proteins, signaling molecules, and the immune and nervous systems. $\mathrm{Zn}$ is important for the functional stability of receptors. Its deficiency causes disturbances in immunity, osseous tissue development, reproductive system and gastrointestinal tract functions; it has a negative effect on skin, DNA, and neoplastic processes $[15,16]$. Pregnant women and children are especially sensitive to $\mathrm{Zn}$ deficiency. The worldwide incidence of $\mathrm{Zn}$ deficiency is estimated at approximately two billion people $[3,13]$.

Selenium is needed for normal activity of nearly 50 human enzymes, including glutathione peroxidase with its antioxidant activity, and thyroid deiodinase. A sufficient selenium supply with food is a means to prevent cardiovascular diseases and neoplasia. Se deficiency is observed in approximately $0.5-1.0$ billion people, mostly in developing countries, especially where crops are grown on micronutrient-poor soils, which leads to high incidences of hypothyroidism, cardiomyopathies (Keshan disease), and degenerative dystrophy of the musculoskeletal system (Kashin-Beck disease) $[1,3,13,15,16]$.

Calcium is one of the important macronutrients and principal structural component in the human musculoskeletal system and teeth. Like zinc, calcium is a cofactor for a number of key enzymes in the blood coagulation system; its deficiency threatens children with rickets, and elderly people with osteoporosis and coagulation disorders [17].

Iodine (I), iron (Fe), zinc $(\mathrm{Zn})$, calcium $(\mathrm{Ca})$, manganese $(\mathrm{Mn})$ and selenium $(\mathrm{Se})$ are found in many food products, albeit in limited amounts. A monotonous diet, such as the one that consists mostly of small grains crops' flour, can provoke their deficiency. Such deficiencies are more common for developing countries, where fresh food (vegetables and fruits) is not freely affordable, while developed countries, as a rule, experience calcium deficiency $[18,19]$.

In addition to mineral components, humans receive with plant food other substances necessary for them, for example, vitamins of groups A, B, C, E, $\beta$-glucans, avenanthramides and other biologically active compounds.

\subsection{Bioactive Compounds, Dietary Fibers and Antioxidants}

Not only micronutrients are important for biofortification, but also other compounds in the composition of SGC grain. Small grains crops are sources of various types of dietary fibers and antioxidants. The oat (Avena sativa L.) grain, for example, contains both insoluble and soluble dietary fibers ( $\beta$-glucans). Beta-glucans possess good functional properties. Physiological effects of $\beta$-glucans are associated with specific features of their structure. Their regular consumption decreases the content of glucose in blood, enhances excretion of bile acids and improves their transport to the lower parts of the gastrointestinal tract, and reduces the blood cholesterol level. Besides, $\beta$-glucans alleviate the course of celiac disease [20], and serve as a preventive measure against ischemic heart disease (especially when the daily dose exceeds $3 \mathrm{~g}$ ) [9-11]. In addition to dietary fibers, oat grain contains avenanthramides (AVA), a class of oat-specific phenolics, which makes oat products indispensable for the population of the regions with a high percentage of skin disorders caused by xerodermia, diabetes or atopic dermatitis [21]. AVA is a unique group of natural alkaloids, contained solely in oat (grain and its hull, leaves, and roots) [22,23]. AVA have been identified in both cultivated and wild oats [24,25]. The interest in AVA is induced by the broad spectrum of their antioxidant, anticancer, antidiabetic, antiatherogenic, anti- 
inflammatory, vasodilating and antipruritic activity [26-30]. In their chemical structure, AVA are diphenolic amides [25,31-36]. Various AVA fractions differ in their bioactivity and bioavailability, which is associated with their chemical structure $[32,37,38]$. The most bioavailable is AVA B. For AVA C, the lowest concentration is observed in blood plasma after consumption, but the products of its metabolism are also bioactive [28,39]. AVA's synergy with other antioxidants, such as vitamins $\mathrm{E}$ and $\mathrm{C}$, is possible [40,41]. There is too little information about the metabolism of AVA in a human organism and mechanisms of their effect. The gut microbiota also participates in AVA metabolism, therefore an individualized approach to human nutrition is required. A synthesized analog of AVA is the pharmaceutical drug Tranilast, currently used in Japan and the Republic of Korea as an antihistamine medication to treat a whole number of allergies [42]. Total AVA content in an oat accession was found to be determined not only by its genotype, but also by the environments where it was reproduced (grown), plus by the genotype-environment interaction [24,25,43,44].

For humans, malnutrition and deficiencies in principal micro- and macronutrients result in growth disturbances and anomalies in physical and mental development. Diseases of alimentary nature are typical for the population of not only countries with low or medium living standards, but also those with highly developed economies, food quality being the main cause of that. The problem could be solved if the required diversity of food products in the daily diet is made available to every individual all over the world, which would secure the normal functional state of all human organs and systems [3].

Reportedly, the so-called 'green revolution', limited to active promotion of modern SGC cultivars and concurrent reduction in the share of traditional legumes in the daily diet, resulted in a serious nutritional imbalance in some countries. The common diet transformed in this way changes the daily human micronutrient consumption. That is why it is necessary to take into consideration many aspects (regional specificity of traditional crop, adaptability of new biofortified varieties for the local specific) for resolving the problem of malnutrition [4]. Small grains crops' flour is the most popular food, but it's not an optimal source of essential amino acids, fatty acids, vitamins, minerals, etc. In order to prevent insufficient intake of the main essential nutrients in the human body, it is necessary to provide a sufficient diversity of food products, including those made from new biofortified SGC varieties $[2,4,5,45]$.

The basic objective in the implementation of any biofortification program is to enrich staple crops with micronutrients, vitamins and other bioactive compounds that ensure normal functioning of the human organism $[2,4,5,45]$.

However, there is another rather significant problem. It lies in the fact that the greater part of the world's population cannot be provided with wholesome food, because products with optimal nutrient composition or biofortified products fall under the category of costly commodities [3].

Such a task may be practically implemented by the scientific community if the entire potential of plant genetic resources at its disposal is employed.

A number of works provide data on releasing biofortified cultivars on the basis of local SGC varieties, already adapted to the conditions of a particular region. Successful exploitation of accessions from plant germplasm collections for the same purpose has also been shown. It was the latter trend that we chose to pay closer attention to. Working with any crop germplasm collection, including that of small grains crops, has serious advantages, because solutions are sought using a fairly comprehensive inter- and intraspecific diversity of accessions. The VIR collection, for example, harbors over 70,000 accessions of SGC from various regions of the world. It contains wild-growing forms, landraces, primitive varieties, and modern improved cultivars. Studying such material with the help of modern scientific techniques, selecting sources and donors of not only a set of target compounds, but also resistance to environmental stressors, and employing them in various breeding programs, including those solving biofortification problems, will provide an opportunity to produce new cultivars with desired properties and expand the assortment of higher-quality food products available to a wider range of consumers [46]. 
The purpose of this work was to examine main approaches associated with a longterm biofortification strategy to eliminate malnutrition, concentrating on a number of SGC as the most popular staple food crops. A special emphasis was made on the potential of plant genetic resources collections, conserved and studied in different countries of the world, including the collection of the N.I. Vavilov Institute of Plant Genetic Resources (VIR) in Russia, as the most convenient and accessible bioresource, possessing the required genetic diversity, which makes it possible to select from the available material the most promising accessions for the development of new biofortified cultivars and improvement of the existing ones.

The work with the VIR collection is presented here, using the results obtained by studying the genetic diversity of oat accessions.

\section{Biofortification Strategy}

Biofortification is a long-term strategy aimed at an increase in the amounts of essential micro- and macronutrients in major food sources that ensure their bioavailability. Biofortification has many tools, the most important of them are shown in Table 2.

Table 2. The main biofortification tools [1-5,45,47].

\begin{tabular}{|c|c|c|c|}
\hline \multirow[b]{2}{*}{ Food Fortification } & \multirow[b]{2}{*}{ Agronomic Strategy } & \multicolumn{2}{|c|}{ Plant Breeding Strategy } \\
\hline & & Conventional & $\begin{array}{c}\text { Genetic Technologies-Based } \\
\text { Breeding Approaches }\end{array}$ \\
\hline $\begin{array}{l}\text { Enrichment of dairy products: } \\
\text { bread, milk, salt, wheat flour, etc. } \\
\text { with essential nutrients } \\
\text { Supplements of micronutrient } \\
\text { and vitamins (pharmacological } \\
\text { preparations of micronutrient } \\
\text { and vitamins) }\end{array}$ & $\begin{array}{l}\text { Mineral fertilization } \\
\text { foliar and soil mineral fertilizing }\end{array}$ & $\begin{array}{l}\text { Using of the genetic variability for } \\
\text { the development of } \\
\text { micronutrient-enhanced } \\
\text { crop varieties }\end{array}$ & $\begin{array}{l}\text { Molecular Breeding } \\
\text { marker-assisted breeding } \\
\text { Genetic Engineering } \\
\text { direct genes introduction into } \\
\text { breeding varieties }\end{array}$ \\
\hline
\end{tabular}

The food products and crops may be used to "deliver" the required micro- and macronutrients to the consumer. Plants consumed traditionally by humans accumulate essential components in the bioavailable form, which facilitates their assimilation by an organism [48]. This approach underpins the so-called biofortification strategy to combat various types of hunger.

\subsection{Food Fortification}

The targets for enrichment should be either food crops themselves or products of their processing, provided that they are commonly used in this or that region. In 1990, for example, iodized salt started to be used against thyroid diseases. Later, the flour enriched with zinc, iron sulfate and folic acid was introduced into usage, then the vegetable oil with vitamins $\mathrm{A}$ and $\mathrm{D}$, and sugar with vitamin $\mathrm{A}$. Wheat (Triticum aestivum $\mathrm{L}$.) flours, vegetable and fruit juices, milk and other food products are supplemented simultaneously with several essential elements ( $\mathrm{Zn}$ and Fe, Ca and Se; vitamins A and D; B9 and Fe) [48]. It has to be added that expanding the assortment of biofortified products is crucial not only for developing countries, but also for developed ones.

\subsection{Agricultural Practices}

\subsubsection{Fertilizers Application to Enrich the Nutrient's Content in SGC Grains}

Biofortified crops may be produced using various agricultural practices: incorporating fertilizers into the soil, sprinkling leaf blades with fertilizer solutions, etc. Such techniques make it possible to increase not only yield, but also nutritional value of small grains crops. In Finland and New Zealand, agricultural practices were used to solve the problem of selenium deficiency in the population's daily diet. In China, applying iodine-containing fertilizers during watering operations on rice (Oryza sativa L.) fields increased the iodine amount in rice NPK kernels. Selecting fertilizers and combining them with each other and 
with non-root feeding had a strong effect on both grain yield and grain quality, as witnessed by S. Chwil [47]. For example, adding nitrogen, phosphorus and potassium fertilizers to the soil would improve iron, zinc and selenium assimilation by plants [48]. Optimal utilization of fertilizers, nitrogen ones included, was also discussed in the publication by J.M. Shah et al. [49]. As mentioned previously, SGC quality may be improved using various fertilization techniques. For example, Mohsen Janmohammadi et al., while experimenting with barley (Hordeum vulgare L.), assessed the field application of slurries containing chelated iron and zinc oxide nanoparticles [50]. A team of researchers showed that using chelated forms of Helatonik and Nutrivant Plus Cereals fertilizers for foliar feeding of spring barley under the arid agriculture conditions of Middle Volga provides up to $26 \%$ yield increase, concurrently retaining high grain quality [51,52]. Shahab Khaghani analyzed how the root system development in H. vulgare (cv. 'Bahman') was affected by a fungal culture of Glomus intraradices combined with various concentrations of fertilizers containing iron (Sequestrene 138) and zinc sulfate [53].

It is not a secret that part of fertilizers applied to the soil are not utilized by plants and become a source of environmental pollution, entailing a negative effect on human health. Therefore, environmental safety of crop farming is one of the major aspects in the production of healthy food. F.H.M. Tang and F.B. Maggi assessed the possibility to use human urine as a fertilizer for staple food crop production, which is especially important for large urban areas [54]. Jawad Munawar Shah et al. studied the efficiency of soil nitrogen utilization by plants. Testing different wild (XZ56 and XZ149) and cultivated (HXRL and ZD9) barley genotypes resulted in identifying ZD9 and XZ149 as N-efficient. Higher nitrogen levels in their tissues induced a considerable increase in the content of $\mathrm{P}, \mathrm{K}, \mathrm{Ca}$, $\mathrm{Fe}, \mathrm{Cu}$ and $\mathrm{Mn}$. The chloroplast structure in ZD9 and XZ149 appeared more resistant to nitrogen deficiency due to a higher activity of nitrogen metabolism enzymes (nitrate reductase, glutamine synthetase, nitrite reductase, glutamate synthase, and glutamate dehydrogenase) [49].

Using fertilizers to obtain products with a required chemical composition is not always economically justified, as it can make such products more costly and less available to the needy [45].

\subsubsection{Increasing Micronutrient's Concentration in SGC Grains on Depleted Soils}

Applying different options of fertilizers when growing oat on zinc-deficient soils in Brazil had an effect on the micronutrient's content in the grain [55]. Another study uncovered that the barley landrace 'Sahara' was able to better accumulate zinc in its kernels than the popular cultivar 'Clipper' (both were supplied by the Australian Winter Cereal Collection) when grown on different soil types in Western Australia [56]. Shivay et al. observed that fertilizing zinc-deficient soil in oat fields near Delhi not only increased the yield, but also raised the micronutrient concentration in kernels to the levels required for biofortification purposes [57]. In the southeast of Portugal, where soils are zinc-deficient, 10 advanced breeding lines and three commercial cultivars of bread-making wheat were tested for zinc content in grain. Fertilizers were applied to the soil and sprinkled on the leaf blades; after such treatment, the amount of zinc in grain increased by more than $20 \mathrm{mg} \mathrm{kg}^{-1}$. This study proved a statistically significant effect of the genotype of wheat plants on their ability to assimilate a micronutrient from the fertilized soil and sprinkled foliage. Cvs. INIAV-1, INIAV-6, INIAV-9 and 'Ardila', which combined high yields with sufficient levels of zinc accumulation in grain $\left(45 \mathrm{mg} \mathrm{Zn} \mathrm{kg}^{-1}\right)$, were recommended for solving the problem of zinc deficiency in food, faced by approximately $10 \%$ of the population in Spain and Portugal [58]. 


\section{Plant Breeding Strategy}

\subsection{Conventional Plant Breeding}

3.1.1. Studying of SGC Genetic Resources to Find Sources for Biofortification Breeding Programs

Traditional biofortification breeding approach involves crosses between crop forms with high amounts of target compounds and varieties adapted to local environments. This approach requires assessing the existing biodiversity of the most popular food crops, identifying crop accessions with sufficient levels of target compounds, and testing the stability of these traits under various growing conditions, i.e., finding varieties adapted to local environments. With this in view, improvement of the required characters should not affect the yield or nutritional value of the tested crop varieties [45].

The analysis of barley grown in Finland showed that the total content of folic acid in grain could reach $773 \mathrm{ng} / \mathrm{g}$ [9]. The study of 18 A. sativa genotypes in North Dakota, USA, resulted in finding that the content of $\beta$-glucan in oat kernels was $5.2 \%$, ash was $1.9 \%$, potassium was $3419 \mathrm{ppm}$, magnesium was $1416 \mathrm{ppm}$, calcium was $441 \mathrm{ppm}$, iron was $52 \mathrm{ppm}$, zinc was $26 \mathrm{ppm}$, and selenium was $0.38 \mathrm{ppm}$ [59]. Among the studied germplasm, the Italian cultivar 'Novella Antonia' (A. sativa) was singled out for its higher $\alpha$-tocopherol, $\alpha$-tocotrienol and ß-tocotrienol contents. High levels of AVA (up to $3.0 \mathrm{~g} \mathrm{~kg}^{-1}$ ) were found in few A. sativa accessions, like 'Glasnevin Triumph', and an accession of $A$. byzantina. The study revealed a fairly wide diversity of Avena accessions in the antioxidant activity indicators and confirmed that biochemical parameters of oat grain are influenced by not only the environment, but also close interaction between abiotic factors and genetic features of the crop. [24]. In A. sativa cultivars, AVA may range within $25-80 \%$ of the total amount of soluble phenols in grain [60]; therefore, this species is notable for its extensive genetic variability both in the total AVA and in their separate fractions. North American cultivars contained 18.3-163.4 mg/g of AVA, with their maximum in cv. 'Deiter' [61]. In Chinese naked oat cultivars, the total AVA content varied within $3.73-71.85 \mathrm{mg} / \mathrm{g}$ DW [62]. According to Chen et al. [41], the maximum value of the total AVA in the group of Chinese cultivars was 29.3 times higher than the minimum $(5.01-146.94 \mu \mathrm{g} / \mathrm{g})$. The highest content was observed in the hulled cultivars 'Longyan 3' (146.94 $\mu \mathrm{g} / \mathrm{g}$ ) and 'Beiyan 1' (120.95). When 29 naked and 10 hulled Chinese cultivars were reproduced in four regions of China, the total AVA content in the accessions varied in the range of $22.1-471.2 \mathrm{mg} / \mathrm{kg}$. Meanwhile, 113 accessions ( $72.4 \%$ of the entire set) showed $30-120 \mathrm{mg} / \mathrm{kg}$, and in only four accessions $(2.6 \%)$ it exceeded $300 \mathrm{mg} / \mathrm{kg}$. The levels of major AVA also varied considerably: AVA C within 6.24-136.20 mg/kg, AVA A within 6.07-112.25, and AVA B within 7.26-222.77 [44]. The basic effect on the variability of this character was produced by the environment. The highest AVA values were recorded for the accessions reproduced in Gansu. The naked cv. 'Bayou 9' manifested there the maximum in AVA $(471.2 \mathrm{mg} / \mathrm{kg})$; its values for the same cultivar in three other regions varied from 48.2 to $190.8 \mathrm{mg} / \mathrm{kg}$. The total content of three main AVA in the groat of Mexican cultivars varied within $1.8-9.9 \mathrm{mg} / \mathrm{kg}$; with this, the cultivars differed in the content of individual fractions. The maximum was observed in the genetically modified cv. 'Avemex' [63]. In Finnish hulled oats, total AVA varied from 26.7 (cv. 'Avetron') to $185 \mathrm{mg} / \mathrm{kg}$ (cv. 'Viviana'), the latter showing the highest values of AVA C $(39.2 \mathrm{mg} / \mathrm{kg})$, AVA A (29.6), and AVA B (21.9) [64,65]. In Czechia, cvs. 'Shadow' (Canada), 'Valiant' (Netherlands) and 'Atego' (Czech Republic) were identified for total AVA levels exceeding $250 \mathrm{mg} / \mathrm{kg}$ DW [36]. According to Leonova et al. [25], total AVA in 160 wild and cultivated oat accessions reproduced in 2010-2014 varied from 4 to $1825 \mathrm{mg} / \mathrm{kg}$ WW. In some years, high AVA values were recorded for accessions of $A$. sterilis (nearly $2 \mathrm{~g} / \mathrm{kg}$ ), A. insularis and A. longiglumis $(600-700 \mathrm{mg} / \mathrm{kg}$ ), and A. sativa (cv. 'Numbat', $551.35 \mathrm{mg} / \mathrm{kg}$ ). It has already been mentioned that the AVA content is influenced by the growing conditions, including agricultural practices employed. An increase in the nitrogen level due to fertilization was found to be accompanied by reduced AVA levels in the grain of winter oat cultivars. With this in view, cultivars with higher AVA contents (cvs. 'Mascani' and 'Tardis') responded more expressly to changes in the soil nitrogen concentrations than 
those with lower values (semidwarf cv. 'Balado', and cv. 'Gerald') [66]. Significant genetic variability in the populations of small grain crops including $A$. sativa is a prerequisite to select cultivars that may serve as potential sources of high content of bioactive compounds like AVA during their certification trials and zoning. Complex evaluation of the oat grain composition revealed positive correlations between total AVA and protein, and between AVA and ash, i.e., total minerals [62,63]. Germinated oat kernels can also serve as AVA sources. In this case, the composition of these compounds will change in the sprouted plantlets, and their content may become up to 25 times higher than in seeds, depending on the cultivar [34,66]. Although AVA do not possess high heat resistance, novel processing techniques make it possible to preserve them in the customer-targeted end products [67]. Analyzing 45 oat products showed that the AVA content in oat flour $(33-70 \mu \mathrm{g} / \mathrm{g})$, oat bran (33-94) and oat cereal (25-78) was matchable with that in whole grain oats (37-45). If the share of oat raw material in the finished product is small, the AVA content will also be insignificant, as, for example, in oat biscuits and bread (5-6 $\mu \mathrm{g} / \mathrm{g}$ ) [33]. These data are in line with the results obtained by other experts [68]. AVA's amounts given in this section are shown in Table 3.

Table 3. Avenanthramide's contents in oat varieties, cultivars and oat products.

\begin{tabular}{|c|c|}
\hline Oat varieties, Cultivars, Oat Products & Avenanthramide's Amounts \\
\hline $\begin{array}{l}\text { European } A \text {. sativa cultivars and } \\
\text { A. byzantine cultivars }\end{array}$ & total AVA: up to $3.0 \mathrm{~g} / \mathrm{kg}$ [24] \\
\hline North American A. sativa cultivars & total AVA: 18.3-163.4 mg/g [61] \\
\hline Chinese naked oat cultivars & total AVA: $3.73-71.85 \mathrm{mg} / \mathrm{g}$ DW [62] \\
\hline Chinese hulled oat cultivars & total AVA: 5.01-146.94 $\mu \mathrm{g} / \mathrm{g}[41]$ \\
\hline (cv 'Longyan 3'; & total AVA: $146.94 \mu \mathrm{g} / \mathrm{g}$ [41] \\
\hline cv ‘Beiyan 1’) & total AVA: $120.95 \mu \mathrm{g} / \mathrm{g}$ [41] \\
\hline \multicolumn{2}{|l|}{ Chinese 29 naked and 10 hulled cultivars } \\
\hline$-»-$ & total AVA: $22.1-471.2 \mathrm{mg} / \mathrm{kg}[44]$ \\
\hline$-»-$ & AVA C: $6.24-136.20 \mathrm{mg} / \mathrm{kg}[44]$ \\
\hline$-»-$ & AVA A: $6.07-112.25 \mathrm{mg} / \mathrm{kg}[44]$ \\
\hline $\begin{array}{c}\text { naked cv. 'Bayou 9(reproduced in Gansu } \\
\text { region of China) }\end{array}$ & $\begin{array}{l}\text { AVA B: } 7.26-222.77 \mathrm{mg} / \mathrm{kg}[44] \\
\text { total AVA: } 471.2 \mathrm{mg} / \mathrm{kg}[44]\end{array}$ \\
\hline $\begin{array}{c}\text { naked cv. 'Bayou } 9 \text { (reproduced in other } \\
\text { regions of China) }\end{array}$ & total AVA: 48.2 to $190.8 \mathrm{mg} / \mathrm{kg}$ [44] \\
\hline $\begin{array}{l}\text { Mexican A. sativa cultivars } \\
\text { (modified cv. 'Avemex') }\end{array}$ & $\begin{array}{c}\text { total AVA: } 1.8-9.9 \mathrm{mg} / \mathrm{kg}[63] \\
\text { total AVA: } 9.9 \mathrm{mg} / \mathrm{kg}[63] \\
\text { total AVA: } 26.7 \mathrm{mg} / \mathrm{kg}[64]\end{array}$ \\
\hline $\begin{array}{l}\text { Finnish hulled oats: cv. 'Avetron' } \\
\text { cv. 'Viviana' }\end{array}$ & $\begin{array}{l}\text { total AVA: } 185 \mathrm{mg} / \mathrm{kg}[64] \\
\text { AVA C: } 39.2 \mathrm{mg} / \mathrm{kg}[64] \\
\text { AVA A: } 29.6 \mathrm{mg} / \mathrm{kg}[64] \\
\text { AVA B: } 21.9 \mathrm{mg} / \mathrm{kg}[64]\end{array}$ \\
\hline $\begin{array}{l}\text { A. sativa cultivars (cv. 'Shadow' (Canada); } \\
\text { 'Valiant' (Netherlands); 'Atego' (Czech } \\
\text { Republic) reproduced in Czechia }\end{array}$ & total AVA: over $250 \mathrm{mg} / \mathrm{kg}$ DW [36] \\
\hline $\begin{array}{c}160 \text { wild and cultivated Avena accessions } \\
\text { reproduced in Russia: } \\
\text { A. sterilis } \\
\text { A. insularis and A. longiglumis } \\
\text { A. sativa }\end{array}$ & $\begin{array}{l}\text { total AVA: } 4-1825 \mathrm{mg} / \mathrm{kg} \mathrm{WW} \mathrm{[25]} \\
\text { total AVA: nearly } 2 \mathrm{mg} / \mathrm{kg} \text { WW [25] } \\
\text { total AVA: } 600-700 \mathrm{mg} / \mathrm{kg} \text { WW [25] } \\
\text { total AVA: } 551.35 \mathrm{mg} / \mathrm{kg} \mathrm{WW} \mathrm{[25]}\end{array}$ \\
\hline
\end{tabular}

3.1.2. Development of Biofortified SGC Cultivars under Irrigated and Non-Irrigated Conditions

Pursuing a decrease in the incidence of iron deficiency anemia in Central Asian countries and Kazakhstan, dihaploid bread wheat lines were selected for their stable high Fe content under both irrigated and non-irrigated cultivation conditions. These lines can serve as promising sources for the biofortification trend in wheat breeding: DHL-1 (70 and $60 \mathrm{mg} \mathrm{kg}^{-1}$ ), DHL-3 (63 and $60 \mathrm{mg} \mathrm{kg}^{-1}$ ), DHL-9 (63 and $\left.61 \mathrm{mg} \mathrm{kg}^{-1}\right)$, DHL-41 (61 
and $69 \mathrm{mg} \mathrm{kg}^{-1}$ ), and DHL-54 (67 and $60 \mathrm{mg} \mathrm{kg}^{-1}$ ) [59,69] observed higher Fe levels $\left(\geq 60 \mathrm{mg} \mathrm{kg}^{-1}\right)$ in a majority of spring barley cultivars under the conditions of Almaty Region, which allowed them to recognize the potential of the studied area for biofortified crop production.

\subsection{Genetic Biofortification}

One more biofortification approach is based on improvement of cultivar genotypes. It can be done via traditional breeding or genetic technologies-based breeding approaches, such as marker-assisted selection or next-generation breeding (combination of genome editing with traditional breeding). Traditional breeding techniques are combined with genetic technologies-based breeding approaches to accelerate the process. Higher micronutrient concentrations in staple crop grains may be achieved through the expression of genes controlling the activity of micronutrient-carrying proteins, reductases and enzymes, phytosiderophore synthesis, etc. [45]. For this purpose, plant forms with high content of target compounds (minerals, vitamins, other biology active substances) and tolerant to the different stress factors are most promising for hybridization and need to be selected. Usually, such forms may be found among wild relatives of cultivated wheat, oat, barley, rice, etc. As for genetic modifications of staple food crop accessions, the impact of their use on human health remains underexplored. Some countries introduce barriers and formal bans on both cultivation and distribution of genetically modified crops [15,70].

Finding solutions to nutritional integrity problems of human diet on a planetary scale requires the use of the entire scientific potential available now. Efforts have been made to produce multibiofortified cultivars, e.g., by simultaneous enrichment of grain with several valuable components: iron, zinc and vitamin A; folic acid, selenium, tryptophan and lysine, etc. [4].

Current efforts are mainly focused on solving the problem of $\mathrm{Fe}$, I and vitamin A deficiencies, although the deficiency in $\mathrm{Zn}, \mathrm{Cu}$, Se and other vitamins (e.g., riboflavin, vitamin C and vitamin B12) in the daily diet remains a no less urgent problem [4].

To meet biofortification challenges, genetic studies are vigorously going on for staple SGC. Behzad et al. conducted an experiment to locate genes controlling the content and distribution of micronutrients in barley kernels. A number of quantitative trait loci (QTL) were identified under both field and glasshouse conditions, which attested to their relative independence from the environments, while molecular markers on the short arm of chromosome $2 \mathrm{H}$ were recommended for use in breeding programs to develop highyielding barley cultivars with an increased Zn content in grains [56]. Three-year trials of 369 elite cultivars of winter (355 cvs.) and spring ( $14 \mathrm{cvs}$.) wheat from 13 European countries (Germany, France, Poland, Denmark, Austria, Czech Republic, United Kingdom, Sweden, Switzerland, Hungary, Italy, Belgium, and The Netherlands) revealed that the amount of zinc in wheat kernels was strongly affected by not only the genotype, but also the ecogeographic environment of the cultivar's growing area. Zinc content in the tested accessions varied from 25.05 to $52.65 \mu \mathrm{g} \mathrm{g}{ }^{-1}$. Cv. 'Haven' manifested the highest values (52.67 $\left.\mathrm{\mu g} \mathrm{g}^{-1} \mathrm{DW}\right)$. It was shown that chromosome segments $3 \mathrm{~B}$ and $5 \mathrm{~A}$, associated with genes regulating zinc accumulation in wheat grain, such as MAPK and bZIP, might be used in the future for the development of cultivars with high zinc levels [71]. Swamy et al. performed successful experiments on crossing the popular high-yielding rice cultivar 'Swarna' with the accessions of the wild rice species O. nivara (IRGC81848 and IRGC81832), which had high levels of zinc and iron content in grain. The researchers found out that a majority of QTL alleles responsible for micronutrient concentrations were located in $O$. nivara. Thus, crosses with wild forms led to the release of high-yielding rice lines with high zinc and iron concentrations in their grain, which may help to solve the problem of micronutrient deficiency in food products [72]. An increase in the activity of functionally overlapping heavy metal transporting P1B-ATPases (HMAs) can also be employed to obtain SGC cultivars with a higher zinc content in their endosperm [73]. Xue et al. analyzed the impact of the genotype and climate conditions on the content of some macro- and 
micronutrients in grain of 60 lines in a barley RIL (recombinant inbred line) population from crosses between cvs. 'Karl' and 'Lewis', segregating for the SSR marker Hvm74, linked to grain protein content (GPC) locus (HvNAM-1), which controls protein level in the environments of Yunnan-Guizhou Plateau, Southern China. Micronutrient amounts significantly depended on the interactions between genetic and weather factors. Besides, Xue et al. assumed that the genes of the GPC locus may affect the accumulation of certain bioactive compounds (phytate, phenolics and flavonoids) and micronutrients ( $\mathrm{P}, \mathrm{Zn}$ and $\mathrm{Fe}$ ) in grain, especially $\mathrm{Zn}$ and $\mathrm{Fe}$, which may be used in future to expand the assortment of biofortified produce [74].

The research results obtained for wheat accessions from the International Maize and Wheat Improvement Center (CIMMYT, Mexico) showed that the highest Fe and Zn contents were registered for T. dicoccum Schrank (29-57 and 25-53 $\mathrm{\mu g} \mathrm{g}^{-1}$, respectively) [75]. According to the data of the International Rice Research Institute (IRRI, Philippines), high Fe and $\mathrm{Zn}$ content values (18-22 and 24-35 $\mu \mathrm{g} \mathrm{g}^{-1}$, respectively) were identified for the grain of the aromatic rice lines Jalmagna, Zuchem and Xua Bue Nuo [4]. The experiment performed by George et al. in Scotland ascertained that traditional landraces of barley (H. vulgare), small oat (A. strigosa Schreb.) and common oat (A. sativa), when grown on local alkaline soil, accumulated manganese much better than their commercial analogs [76].

\section{Micronutrient Bioavailability and Safety}

Antinutrients convert micronutrients into forms that cannot be assimilated by the human organism. They include phytic acid, oxalic acid, tannins, etc. The presence of phytic acid salts (D-myo-inositol, 1,2,3,4,5,6-hexakis [dihydrogen phosphate]) in food contributes to a decrease in the amount of iron delivered to the human organism. In other words, those who work on biofortified cultivar development should take into account the problem of micronutrient bioavailability [45]. In this regard, mutagenesis was used to develop barley, rice cultivars with low levels of phytic acid content [77]. Wheat and rice cultivars with the fungal phytase gene $[78,79]$ improve iron assimilation; SGC cultivars with a low oxalic acid content [80] increase calcium assimilation.

Soil composition can include trace elements that produce a negative effect on human health. For example, cadmium, even in small concentrations, is toxic to live tissues. It contributes to a loss of calcium by the human organism, provokes osteoporosis manifestations and neoplastic processes. That is why scientists are working on mitigating the hazards of toxic compound accumulation in plant tissues. Tanhuanpää et al. [81], for example, concentrated their efforts on the search for DNA markers capable of identifying oat genotypes with low cadmium accumulation rates in grain. The spring oat cultivars 'Aslak' and 'Salo', and their hybrids, grown in glasshouses, were used to identify four DNA markers important for breeding.

Among the research trends of high demand, are those studying the interplay between the accumulation of harmful components (cadmium) in plant tissues and human-friendly micronutrient levels. Detterbeck et al. [82] analyzed 136 lines of $H$. vulgare L. (landraces and cultivars) from the genebank department of the Leibniz Institute of Plant Genetics and Crop Plant Research, Gatersleben, and found out that zinc and manganese accumulated mostly in the embryo tissues of oat grain, if compared with the endosperm or hull, whereas iron amassed in aleurone cells. For barley, an increase in grain zinc content occurred simultaneously with a cadmium increase. This study confirmed close connections between $\mathrm{Zn}, \mathrm{Mn}$ and Cd amounts in H. vulgare kernels. Meanwhile, using the potential of SGC genetic resources from genebanks of different countries may help to find source materials combining low cadmium content in grain and high values of target micronutrients. Such sources may be successfully employed in fortification breeding programs [82]. Other researchers investigated the effect of the presence of cerium and titanium oxide nanoparticles in soil on barley grain quality indicators. The presence of such nanoparticles had a negative effect on the yield in general and on the amylose content in grain, but its effect was positive for the total protein amount, the content of most amino acids (especially lysine), and the 
levels of micronutrients ( $\mathrm{Ca}, \mathrm{Mg}$ and $\mathrm{Zn}$ ). Such experience underlines the vital importance of learning about the effect of nanofactors on the basic indicators of grain biofortification value [83]. It was proved that organic and mineral fertilizers coerced staple crop grains to accumulate more trace elements, and not only those eligible for healthy nutrition ( $\mathrm{Zn}, \mathrm{Cu}$ or $\mathrm{Ni}$ ), but also toxic for a human organism (As, $\mathrm{Pb}$ and $\mathrm{Cd}$ ). Moreno et al. [84] analyzed the results of applying biochar in combinations with organic (compost and sewage sludge) and inorganic (NPK and nitrosulfate) fertilizers in the central part of the Iberian Peninsula (Spain) and its effect on the qualitative composition of barley grain. They found out that biochar application reduced the content of $\mathrm{Pb}$ and $\mathrm{Cd}$, but slightly raised the As amount, with practically no effect on the $\mathrm{Zn}, \mathrm{Cu}$ and Ni levels. Moreno et al. concluded that the use of biochar, inter alia, for biofortification purposes had great potential, but required further research [84].

The possibility of increasing the content of $\mathrm{Fe}$ and $\mathrm{Zn}$ with a simultaneous decrease in $\mathrm{Pb}$ and $\mathrm{Cd}$ in SGC grains has been studied for a long time. Ishikawa et al. showed that an increase in phloem-sap concentrations of DMA (2'-deoxymugineic acid) and NA (nicotianamine) contributed to zinc and iron accumulation, and a decrease in OsNRAMP5 (rice natural resistance-associated macrophage protein5) led to an abrupt drop in cadmium in rice kernels [85]. Masuda et al. confirmed that an increase in DMA and NA levels in rice grains correlated with enhanced $\mathrm{Fe}, \mathrm{Zn}$ and $\mathrm{Cu}$ concentrations in them [86]. Goto et al. observed that iron content directly depended on the amount of ferritin in rice grain [87] Ishikawa et al. selected rice accessions with a mutation in OsNRAMP5, responsible for cadmium transport in plants, that demonstrated low cadmium content in grain [88].

\section{Studying Collections of Plant Genetic Resources for Biofortification Purposes \\ 5.1. Collections of SGC Plant Genetic Resources and Biofortification Strategy}

Plant genetic resources are a source of all components guaranteed by evolution to support human life functions. The work with them prioritizes comprehensive studying of the worldwide diversity of cultivated plants and their wild relatives in order to disclose their potential in the context of the most important traits, which will make it possible to improve existing cultivars and develop new ones to meet the most important human need for wholesome nutrition. [46,89]. Ma et al. searched for sources of high iron content for biofortification purposes in two collections of geographically diverse barley genetic resources: Barley Germplasm Center of the Research Institute for Bioresources, Okayama University (274 accessions), and Barley Core Collection of Americas (135 accessions). The highest iron content with a wide range of variation $\left(21.0-83.0 \mathrm{mg} \mathrm{kg}^{-1}\right)$ was observed in naked barley accessions, their origin having no effect on this trait. Ma et al. admitted the need for more profound studies into the physiology of the processes whereby plants extract micronutrients from the soil, transport them to and accumulate in their tissues in order to use the resulting data in biofortification breeding programs [90]. At present, this issue is incessantly investigated [91]. According to Redaelli et al. [24], who assessed the content of major oat antioxidants (tocopherols, tocotrienols, and AVA), the grain of various Avena spp. from European plant genetic resources collections stably demonstrated higher levels of $\alpha$-tocopherol (6-65 mg kg ${ }^{-1} 289$ ), $\alpha$-tocotrienol (4-135 $\mathrm{mg} \mathrm{kg}^{-1} 290$ ), and AVA (up to $4.1 \mathrm{~g} \mathrm{~kg}^{-1}$ ) than other SGC involved into the research. Kaur et al. [92] identified A. sativa genotypes OL-1843, OL-1873 and OL-1865 from the Department of Plant Breeding and Genetics, Punjab Agricultural University, with high levels of starch, sugars (fructose included), protein, zinc, iron, and dietary fibers, and a low content of antinutrients (phytic acid, saponins and tannins) for further ecogeographic research and use in breeding programs [9]. A long-term ecogeographic study was undertaken to test 650 oat accessions representing wild relatives, landraces, traditional, obsolete and modern cultivars selected from European plant genetic resources databases. The tests showed that A. strigosa accessions contained significant amounts of $\alpha$-tocotrienol, $\alpha$ - and $\beta$-tocopherols, and AVA up to $4.1 \mathrm{~g} \mathrm{~kg}^{-1}$, whereas wild A. hirtula and A. barbata were distinguished for $\gamma$ - and $\delta$-tocopherols [24]. A testing of 137 accessions representing European cultivated 
and wild oats, reproduced in seven regions of Europe, resulted in identifying accessions with the highest AVA content: A. strigosa $(1.9-4.1 \mathrm{~g} / \mathrm{kg})$ grown in Bulgaria, and A. strigosa (2.6-3.8), A. byzantina (1.8) and A. sativa (cvs. 'Magda' and 'Glasnevin Triumph' had 1.7 and $2.7 \mathrm{~g} / \mathrm{kg}$, respectively) grown in Sweden. Maximums were recorded for wild oat forms (240-1585 mg/kg) [24].

\subsection{The Potential of VIR Collection of Oat Genetic Resources in Biofortification Strategy}

It was mentioned earlier that a decisive role in the search for biofortification breeding solutions must be played by the ex situ collections of SGC genetic resources maintained in many countries, including the collection held by the N.I. Vavilov All-Russian Institute of Plant Genetic Resources (VIR), with its vast diversity of SGC accessions.

There are approximately 14,000 accessions of Avena L. in VIR's holdings. These are wild oat species and a worldwide diversity of cultivated oats, represented by landraces, cultigen populations, obsolete cultivars, modern improved cultivars, and breeding lines. They have integrated the complete geographic diversity from all continents. Complex studies of this material enable researchers to identify sources for plant breeding and submit them to leading breeding centers over Russia for crop improvement [89,93-97].

VIR's research efforts helped to select SGC accessions with the biochemical composition optimal for solving biofortification tasks in the environments of Leningrad Province, Russia. Among the selected oat accessions, were those resistant to Fusarium and containing high amounts of the vitamin F (linoleic, linolenic and arachidonic fatty acids): cvs. 'Argamak', 'Sig', 'Kreol', 'Otrada', 'Rovesnik' (Russia); 'Boog' (Belarus); 'Circle', 'SW Ingeborg' (Sweden); 'Borrus', 'KWS Contender', 'Scorpion', 'Typhoon' (Germany); 'Denton Dwarf' (Denmark), etc. $[95,98]$. The study conducted by Leonova et al. [97] ascertained that the content of oil is typically higher in wild oats, while that of essential polyunsaturated fatty acids (linoleic and linolenic) is higher in cultivated ones. The identified accessions of A. sativa (cvs. 'Fakir' and 'Allur', Russia) had the following respective levels of these acids: 43.1 and $1.5 \% ; 43.1$ and $2.1 \%$ [97]. The hexaploid wild species $A$. occidentalis demonstrated significant amounts of vitamin $\mathrm{F}$ and sitosterol; the latter compound was high in the tertraploid A. agadiriana and hexaploid A. sterilis [94]. Bityutskii et al. [50] studied SGC accessions from VIR and found out that the oat and barley germplasm collections held by VIR could be used by breeders as sources of higher essential micronutrient content. For example, barley cvs. 'S79b-Morex' (Germany) and 'Galleon' (USA) had the highest Fe content. In addition, 'Galleon' showed the highest levels of Zn (32 $\left.\mathrm{mg} \mathrm{kg}^{-1}\right)$ and Mn (21 $\mathrm{mg} \mathrm{kg}^{-1}$ ). 'Vada' (Netherlands) and 'Haruna Nijo' (Japan) had relatively high total micronutrient contents. Among oat cultivars, 'Rovesnik' and 'Pamyati Balavina' (Russia) demonstrated the highest Fe content (C36 mg kg-1). "Rovesnik" was the best not only in Fe but also in $\mathrm{Zn}$ and Mn [99]. In another research project, Bityutskii et al. [100] observed that the oat accessions from VIR possessed high potential for the development of new advanced cultivars combining high protein and oil contents in grain with sufficient concentrations of major micronutrients, so they could prove instrumental in solving biofortification tasks. In addition to the well-balanced micronutrient composition, grains of wild $A$. sterilis forms are able to accumulate considerable amounts of phenolic compounds, such as AVA; their content reached $1825 \mathrm{mg} \mathrm{kg}^{-1}$, against $586 \mathrm{mg} \mathrm{kg}^{-1}$ in cultivated oat grain. Among cultivars, both the lowest ( $12 \mathrm{mg} \mathrm{kg}^{-1}$ ) and highest (up to almost $600 \mathrm{mg} \mathrm{kg}^{-1}$ ) AVA levels were found in naked oat. Our data showed strong influence of environmental conditions on AVA grain, the possibility to use them in breeding programs aimed at the development of biofortified cultivars [96]. Yarosh and Nizova found out that presowing treatment of hulled oat seed with a $0.004 \%$ solution of succinic acid helped to improve grain quality indicators (the content of oil, protein, and vitamins of the B group). The highest levels of protein and oil (higher than the reference by 5-8 and 10-13\%) were identified in cv. 'Astor' (Netherlands), thiamine (by 9-16\%) in 'Hadmerslebener AG' (Germany), and riboflavin (by 13-19\%) in 'Borrus' (Germany) [101]. Many years of researching a set of naked oat varieties from the VIR collection resulted in finding stably high levels of thiamine (9.83-11.61 
$\mathrm{mg} / \mathrm{kg}$ ) and riboflavin (1.84-1.94 mg/kg) in cv. 'Pioner', WIR-2301 (Russia) and cv. 'Platek' (Poland); only thiamine in accessions WIR-10511, WIR-10795 (Russia) and WIR-2468 (Mongolia); only riboflavin in cv. 'Lyubimets' (Russia) and accessions WIR-4958 and WIR-10835 (China). Besides, an optimal ratio of Omega- 3 and Omega- 6 fatty acids in the oil of the identified accessions was close to one [102]. A study employing 82 accessions of $A$. sativa and $A$. byzantina from the VIR collection helped to identify high vitamin $\mathrm{F}$ content in the hulled oat forms WIR-13398 (France), WIR-11840 (Germany) and WIR-13388 (Finland), and the naked accessions WIR-11354 (Germany) and WIR-11213 (Czechia) [103]. Ecogeographic trials involving 13 A. sativa varieties of diverse origin from the VIR collection, performed at the Institute's branch stations in different soil and climate zones of Russia, showed that the environments of the Volga basin were conducive to riboflavin accumulation in oat kernels $(2.14 \mathrm{mg} / \mathrm{kg}$ for hulled oats and 1.80 for naked ones). No reliable relationships were found between thiamine content and environmental factors, although the analysis of variance proved that the latter had a stronger effect on vitamin content than the genotype [104].

Thus, the study of collections of plant genetic resources provides an inexhaustible source for creating new varieties and improving already existing ones with necessary chemical composition with high resistance to stressful environmental conditions, which can be successfully used for biofortification purposes.

\section{Conclusions}

Biofortification is a long-term strategy. To make it efficient for nutritional enrichment of the global diet, it should employ the entire existing potential of SGC genetic resources across different countries and the achievements in various areas of modern biology.

In this review, we have focused on the representatives of SGC, which can be attributed to the most widespread food resources accessible to most of the people. Moreover, SGC are sources of not only highly nutritious protein and carbohydrates, but also micronutrients, vitamins and other bioactive compounds. The content of these compounds in grains of a number of oats, barley and other SGC cultivars reaches values sufficient for normal functioning of a human organism when such cultivars are used in a daily diet.

Development of biofortification trends requires wider utilization of plant genetic diversity to produce cultivars with a targeted biochemical composition, adapted to cultivation in versatile ecogeographic environments, on different soils, including those deficient in micronutrients, which would make food products of higher quality available to a wider range of consumers.

To find solutions to this problem, a comprehensive study of plant genetic resources from the collections located in scientific centers around the world should play an invaluable role, as it would help to develop new SGC cultivars that can be successfully used to eliminate malnutrition.

Author Contributions: Conceptualization T.V.S., A.V.K. and I.G.L.; writing-original draft preparation, T.V.S., Y.A.K., I.N.P. and A.E.S.; writing-review and editing, A.V.K., I.G.L. and E.K.K.; supervision, A.V.K., I.G.L. and E.K.K. All authors have read and agreed to the published version of the manuscript.

Funding: The research was funded in the framework of the State Assignment to VIR in accordance with the Thematic Plan, Topic №. 0662-2019-0006 "Investigation, maintenance of viability and disclosure of the potential of hereditary variability of the VIR world collection of cereals and cereals for the development of an optimized genebank and rational use in breeding and crop production", Registered in the Unified State Information System for Accounting for Research and Development Work under the State Number AAAA-A19-119013090155-7.

Acknowledgments: The authors wish to thank the support of EU-LIFE program under the grant agreement LIFE16 CCA/GR/000050.

Conflicts of Interest: The authors declare no conflict of interest. 


\section{References}

1. Mid-term review of the UN Decade of Action on Nutrition. Available online: https://www.who.int/news-room/detail/12-03-20 20-mid-term-review-of-the-un-decade-of-action-on-nutrition (accessed on 10 August 2020).

2. WHO. Available online: https://www.who.int/docs/default-source/nutritionlibrary/departmental-news/mid-term-review--un-decade-of-action-on-nutrition/nutrition-decade-mtr-foresight-paper-ru.pdf?sfvrsn=9c3e3836_6 (accessed on 10 August 2020).

3. Global Nutrition Report 2020 Stresses Equity Focus to Address Rising Malnutrition. Available online: https://www.harvestplus org/knowledge-market/in-the-news/global-nutrition-report-2020-stresses-equity-focus-address-rising (accessed on 15 August 2020).

4. Welch, R.M.; Graham, R.D. Breeding crops for enhanced micronutrient content. Plant Soil 2002, 245, 205-214. [CrossRef]

5. World Health Organization. 1999. Available online: http://www.who.int/nut/malnutritionworldwide.htm (accessed on 20 August 2020).

6. Panasenko, L.M.; Kartseva, T.V.; Nefedova, Z.V.; Zadorina-Khutornaya, E.V. Role of the main mineral substances in the child nutrition. Russ. Bull. Perinatol. Pediatrics 2018, 63, 122-127. [CrossRef]

7. Bhattacharya, P.T.; Misra, S.R.; Hussain, M. Nutritional Aspects of Essential Trace Elements in Oral Health and Disease: An Extensive Review. Science 2016, 2016, 1-12. [CrossRef] [PubMed]

8. WHO. Vitamin and Mineral Requirements in Human Nutrition Second Edition Vitamin and Mineral Requirements in Human Nutrition: World Health Organization and Food and Agriculture Organization of the United Nations; World Health Organization: Geneva, Switzerland, 2004; 362p.

9. Loskutov, I.G.; Polonskiy, V.I. Content of $\beta$-glucans in oat grain as a perspective direction of breeding for health products and fodder (Review). Agric. Biol. 2017, 52, 646-657. [CrossRef]

10. Polonskiy, V.; Loskutov, I.; Sumina, A. Biological role and health benefits of antioxidant compounds in cereals. Biol. Commun. 2020, 65, 53-67. [CrossRef]

11. Thies, F.; Masson, L.; Boffetta, P.; Kris-Etherton, P. Oats and CVD risk markers: A systematic literature review. Br. J. Nutr. 2014, 112, S19-S30. [CrossRef] [PubMed]

12. Rebrov, V.G.; Gromova, O.A. Vitamins, Macro- and Micronutrients; GEOTAR-Media: Moscow, Russia, 2008; 960p.

13. Mehri, A. Trace Elements in Human Nutrition (II)—An Update. Int. J. Prev. Med. 2020, 11, 2. [PubMed]

14. Ermakov, V.V.; Tyutikov, S.F.; Safonov, V.A. Biogeochemical Indication of Microlementoses; RAS: Moscow, Russia, 2018; 386p, ISBN 978-5-906906-91-5.

15. FAO. Biotechnology in Food and Agriculture. 2000. Available online: http://www.fao.org/biotech/c14doc.htm (accessed on 15 August 2020).

16. World Health Organization and Food and Agriculture Organization of the United Nations. Global Health Risks. 2009. Available online: https:/ / www.who.int/healthinfo/global_burden_disease/GlobalHealthRisks_report_full.pdf (accessed on 15 August 2020).

17. Konikowska, K.; Mandecka, A. Trace Elements in Human Nutrition. In Recent Advances in Trace Elements; Wiley: Hoboken, NJ, USA, 2018; pp. 339-372.

18. Díaz, J.R.; Cagigas, A.D.L.; Rodríguez, R. Micronutrient deficiencies in developing and affluent countries. Eur. J. Clin. Nutr. 2003, 57, S70-S72. [CrossRef] [PubMed]

19. Underwood, B.A. From research to global reality: The micronutrient story. J. Nutr. 1998, 128, 145-151. [CrossRef]

20. Butt, M.S.; Nadeem, M.T.; Khan, M.K.I.; Shabir, R. Oat: Unique among the cereals. Eur. J. Nutr. 2008, 47, 68-79. [CrossRef] [PubMed]

21. Mahmood, K.; Saliou, C.; Wallo, W. Nutrient-Rich Botanicals in Skin Health: Focus on Avena sativa. In Bioactive Dietary Factors and Plant Extracts in Dermatology; Springer Science and Business Media LLC: Berlin/Heidelberg, Germany, 2012 ; pp. 153-168.

22. Collins, F.W. Oat phenolics: Avenanthramides, novel substituted N-cinnamoylanthranilate alkaloids from oat groats and hulls. J. Agric. Food Chem. 1989, 37, 60-66. [CrossRef]

23. Okazaki, Y.; Isobe, T.; Iwata, Y.; Matsukawa, T.; Matsuda, F.; Miyagawa, H.; Ishihara, A.; Nishioka, T.; Iwamura, H. Metabolism of avenanthramide phytoalexins in oats. Plant J. 2004, 39, 560-572. [CrossRef] [PubMed]

24. Redaelli, R.; Dimberg, L.; Germeier, C.U.; Berardo, N.; Locatelli, S.; Guerrini, L. Variability of tocopherols, tocotrienols and avenanthramides contents in European oat germplasm. Euphytica 2016, 207, 273-292. [CrossRef]

25. Leonova, S.; Gnutikov, A.; Loskutov, I.; Blinova, E.; Gustafsson, K.-E.; Olsson, O. Diversity of avenanthramide content in wild and cultivated oats. Proc. Appl. Bot. Genet. Breed. 2020, 181, 30-47. [CrossRef]

26. Tripathi, V.; Singh, A.; Ashraf, M.T. Avenanthramides of Oats: Medicinal Importance and Future Perspectives. Pharmacogn. Rev. 2018, 12, 66-71. [CrossRef]

27. Perrelli, A.; Goitre, L.; Salzano, A.M.; Moglia, A.; Scaloni, A.; Retta, S.F. Biological Activities, Health Benefits, and Therapeutic Properties of Avenanthramides: From Skin Protection to Prevention and Treatment of Cerebrovascular Diseases. Oxidative Med. Cell. Longev. 2018, 2018, 1-17. [CrossRef] [PubMed]

28. Zhang, T.; Shao, J.; Gao, Y.; Chen, C.; Yao, D.; Chu, Y.F.; Johnson, J.; Kang, C.; Yeo, D.; Ji, L.L. Absorption and Elimination of Oat Avenanthramides in Humans after Acute Consumption of Oat Cookies. Oxidative Med. Cell. Longev. 2017, 2017, 1-7. [CrossRef] 
29. Marmouzi, I.; Ezzat, S.M. The Pharmacology of Avenanthramides: Polyphenols. In Polyphenols in Human Health and Disease, 2nd ed.; Watson, R.R., Preedy, V.R., Zibadi, S., Eds.; Academic Press: Salt Lake City, UT, USA, 2018; pp. 3-13.

30. Turrini, E.; Maffei, F.; Milelli, A.; Calcabrini, C.; Fimognari, C. Overview of the Anticancer Profile of Avenanthramides from Oat. Int. J. Mol. Sci. 2019, 20, 4536. [CrossRef]

31. Maliarova, M.; Mrazova, V.; Havrlentova, M.; Sokol, J. Optimization of Parameters for Extraction of Avenanthramides from Oat (Avena sativa L.) Grain Using Response Surface Methodology (RSM). J. Braz. Chem. Soc. 2015, 26, 2369-2378.

32. Ishihara, A.; Kojima, K.; Fujita, T.; Yamamoto, Y.; Nakajima, H. New series of avenanthramides in oat seed. Biosci. Biotechnol. Biochem. 2014, 78, 1975-1983. [CrossRef]

33. Pridal, A.A.; Böttger, W.; Ross, A.B. Analysis of avenanthramides in oat products and estimation of avenanthramide intake in humans. Food Chem. 2018, 253, 93-100. [CrossRef] [PubMed]

34. De Bruijn, W.J.C.; van Dinteren, S.; Gruppen, H.; Vincken, J.-P. Mass spectrometric characterisation of avenanthramides and enhancingtheir production by germination of oat (Avena sativa). Food Chem. 2019, 277, 682-690. [CrossRef] [PubMed]

35. Wu, W.; Tang, Y.; Yang, J.; Idehen, E.; Sang, S. Avenanthramide Aglycones and Glucosides in Oat Bran: Chemical Profile, Levels in Commercial Oat Products, and Cytotoxicity to Human Colon Cancer Cells. J. Agric. Food Chem. 2018, 66, 8005-8014. [CrossRef]

36. Jágr, M.; Dvořáček, V.; Čepková, P.Y.; Doležalová, J. Comprehensive Analysis of Oat Avenanthramides Using Hybrid QuadrupoleOrbitrap Mass Spectrometry: Possible Detection of New Compounds. Rapid Commun. Mass Spectrom. 2018, 34, e8718. [CrossRef] [PubMed]

37. Peterson, D.M.; Martha, J.; Hahn, M.J.; Emmons, C.L. Oat avenanthramides exhibit antioxidant activities in vitro. Food Chem. 2002, 79, 473-478. [CrossRef]

38. Yang, J.; Oub, B.; Wise, M.L.; Chu, Y.-F. In vitro total antioxidant capacity and anti-inflammatory activity of three common oat-derived avenanthramides. Food Chem. 2014, 160, 338-345. [CrossRef]

39. Wang, P.; Chen, H.; Zhu, Y.; McBride, J.; Fu, J.; Sang, S. Oat Avenanthramide-C (2c) Is Biotransformed by Mice and the Human Microbiota into Bioactive Metabolites. J. Nutr. 2015, 145, 239-245. [CrossRef]

40. Chen, C.-Y.; Milbury, P.E.; Kwak, H.-K.; Collins, F.W.; Samuel, P.; Jeffrey, B.; Blumberg, J.B. Avenanthramides and Phenolic Acids from Oats Are Bioavailable and Act Synergistically with Vitamin C to Enhance Hamster and Human LDL Resistance to Oxidation. J. Nutr. 2004, 134, 1459-1466. [CrossRef]

41. Chen, C.; Wang, L.; Wang, R.; Luo, X.; Li, Y.; Li, J.; Li, Y.; Chen, Z. Phenolic contents, cellular antioxidant activity and antiproliferativ capacity of different varieties of oats. Food Chem. 2018, 239, 260-267. [CrossRef]

42. Darakhshan, S.; Pour, A.B. Tranilast: A review of its therapeutic applications. Pharmacol. Res. 2015, 291, 15-28. [CrossRef] [PubMed]

43. Emmons, C.; Peterson, D.M. Antioxidant Activity and Phenolic Content of Oat as Affected by Cultivar and Location. Crop Sci. 2001, 41, 1676-1681. [CrossRef]

44. Li, X.-p.; Li, M.-y.; Ling, A.-j.; Hu, X.-z.; Ma, Z.; Liu, L.; Li, Y.-x. Effects of genotype and environment on avenanthramides and antioxidant activity of oats grown in northwestern China. J. Cereal Sci. 2017, 73, 130-137. [CrossRef]

45. Gómez-Galera, S.; Rojas, E.; Sudhakar, D.; Zhu, C.; Pelacho, A.; Capell, T.; Christou, P. Critical evaluation of strategies for mineral fortification of staple food crops. Transgenic Res. 2009, 19, 165-180. [CrossRef] [PubMed]

46. Konarev, A.V.; Khoreva, V.I. Biochem. Stud. Plant Genet. Resour. VIR; VIR: St. Petersburg, Russia, 2000; 91p.

47. Chwil, S. A study on the effects of foliar feeding under different soil fertilization conditions on the yield structure and quality of common oat (Avena sativa L.). Acta Agrobot. 2014, 67, 109-120. [CrossRef]

48. Lalani, B.; Bechoff, A.; Bennett, B. Which Choice of Delivery Model(s) Works Best to Deliver Fortified Foods? Nutrients 2019, 11, 1594. [CrossRef]

49. Shah, J.; Syed, B.; Jian-bin, Z.; Quan, X.-y.; Essa, A.; Noor, M.; Zhang, G.-p. Nitrogen (N) metabolism related enzyme activities, cell ultrastructure and nutrient contents as affected by $\mathrm{N}$ level and barley genotype. J. Integr. Agric. 2017, 16, 190-198. [CrossRef]

50. Janmohammadi, M.; Shahryar, N.S.; Mojtaba, D. Investigation of foliar application of nano-micronutrientfertilizers and nanotitanium dioxide on some traits of barley. Nouraein Biol. 2016, 62, 148-156. [CrossRef]

51. Gluhovtsev, V.V.; Sanina, N.V.; Apalikov, A.A. Foliar Application of Nutrients for Spring Barley Cultivation in Arid Conditions of Middle Volga. Russ. Agric. Sci. 2016, 42, 121-123. [CrossRef]

52. Savin, T.V.; Abugalieva, A.I.; Cakmak, I.; Savin, E.V. Barley varieties resources on the Fe content in the grain characterization. Proc. Appl. Bot. Genet. Breed. 2013, 171, 81-85.

53. Khaghani, S. The effects of micro elements of iron and zinc on morphological characteristics of mycorrhized barley (Hordeum vulgare L.). J. Crop Ecophysiol. 2016, 10, 339-351.

54. Tang, F.H.M.; Maggi, F. Breakdown, uptake and losses of human urine chemical compounds in barley (Hordeum vulgare) and soybean (Glycine max) agricultural plots. Nutr. Cycl. Agroecosyst. 2016, 104, 221-245. [CrossRef]

55. Oliveira, S.; Tavares, L.C.; Lemes, E.S.; Brunes, A.P.; Dias, I.L.; Meneghello, G.E. Seed treatment of Avena sativa L. with zinc: Physiological quality and performance of initial plans. Semin. Ciências Agrárias 2014, 35, 1131-1142. [CrossRef]

56. Behzad, S.; Rengel, Z.; Li, C. Quantitative trait loci (QTL) of seed Zn accumulation in barley population Clipper X Sahara. J. Plant Nutr. 2015, 38, 1672-1684.

57. Shivay, Y.S.; Prasad, R.; Pal, M. Effect of Sources, Methods and Time of Application of Zinc on Productivity, Zinc Uptake and Use Efficiency of Oats (Avena Sativa L.) Under Zinc Defficient Condition. J. Plant Nutr. 2015, 38, 1372-1382. [CrossRef] 
58. Gomez-Coronado, F.; Poblaciones, M.J.; Almeida, A.S.; Cakmak, I. Zinc (Zn) concentration of bread wheat grown under Mediterranean conditions as affected by genotype and soil/foliar Zn application. Plant Soil 2016, 401, 331-346. [CrossRef]

59. Doehlert, D.C.; Simsek, S.; Thavarajah, D.; Thavarajah, P.; Ohm, J.-B. Detailed Composition Analyses of Diverse Oat Genotype Kernels Grown in Different Environments in North Dakota. Cereal Chem. 2013, 90, 572-578. [CrossRef]

60. Jastrebova, J.; Skoglund, M.; Nilsson, J.; Dimberg, L.H. Selective and sensitive LC-MS determination of avenanthramides in oats Chromatographia 2006, 63, 419-423. [CrossRef]

61. Chu, Y.-F.; Wise, M.L.; Gulvady, A.A.; Chang, T.; Kendra, D.F.; van Klinken, B.J.-W.; Shi, Y.; O'Shea, M. In vitro antioxidant capacity and anti-inflammatory activity of seven common oats. Food Chem. 2013, 139, 426-431. [CrossRef]

62. Tong, L.; Liu, L.; Zhong, K.; Wang, Y.; Guo, L.; Zhou, S. Effects of Cultivar on Phenolic Content and Antioxidant Activity of Naked Oat in China. J. Integr. Agric. 2014, 13, 1809-1816. [CrossRef]

63. Ortiz-Robledo, F.; Villanueva-Fierro, I.; Omaha, B.D.; Lares-Asef, I.; Proal-Nájera, J.B.; Návar-Chaidez, J. Avenanthramides and nutritional components of Four mexican oat (Avena sativa L.) Varieties. Agrociencia 2013, 47, 225-232.

64. Multari, S.; Pihlava, J.-M.; Ollennu-Chuasam, P.; Hietaniemi, V.; Yang, B.; Suomela, J.-P. Identification and Quantification of Avenanthramides and Free and Bound Phenolic Acids in Eight Cultivars of Husked Oat (Avena sativa L.) from Finland. J. Agric. Food Chem. 2018, 66, 2900-2908. [CrossRef]

65. Allwood, J.W.; Xu, Y.; Martinez Martin, P.; Palau, R.; Cowan, A.; Goodacre, R.; Marshall, A.; Stewart, D.; Howarth, C. Rapid UHPLC-MS metabolite profiling and phenotypic assays reveal genotypic impacts of nitrogen supplementation in oats. Metabolomics 2019, 15, 19. [CrossRef] [PubMed]

66. Dinga, J.; Johnsonb, J.; Chub, Y.F.; Fenga, H. Enhancement of $\gamma$-aminobutyric acid, avenanthramides, and other healthpro-moting metabolites in germinating oats (Avena sativa L.) treated with and without power ultrasound. Food Chem. 2019, 283, 239-247. [CrossRef] [PubMed]

67. Kaura, J.; Whitson, A.; Ashton, J.; Katopo, L.; Kasapis, S. Effect of ultra-high temperature processing and storage conditions on phenolic acid, avenanthramide, free fatty acid and volatile profiles from Australian oat grains. Bioact. Carbohydr. Diet. Fibre 2018, 15, 21-29. [CrossRef]

68. Soycan, G.; Schär, M.Y.; Kristek, A.; Boberska, J.; Alsharif, S.N.; Corona, G.; Shewry, P.R.; Spencer, J.P. Composition and content of phenolic acids and avenanthramides in commercial oat products: Are oats an important polyphenol source for consumers? Food Chem. 2019, 3, 100047. [CrossRef]

69. Abugalieva, A.I.; Abugalieva, S.I.; Quarri, S.A.; Turuspekov, E.K.; Chakmak, I.; Savin, T.V.; Ganeev, V.A. Fe, Zn and S content in doubled haploid lines of Chinese spring $\times$ SQ1 wheat population. Vavilov J. Genet. Breed. 2012, 16, 894-901.

70. Frossard, E.; Bucher, M.; Mächler, F.; Mozafar, A.; Hurrell, R. Potential for increasing the content and bioa-vailability of Fe, Zn and Ca in plants for human nutrition. J. Sci. Food Agric. 2000, 80, 861-879. [CrossRef]

71. AlOmari, D.Z.; Eggert, K.; Von Wirén, N.; Alqudah, A.M.; Polley, A.; Plieske, J.; Ganal, M.W.; Pillen, K.; Röder, M. Identifying Candidate Genes for Enhancing Grain Zn Concentration in Wheat. Front. Plant Sci. 2018, 9. [CrossRef]

72. Swamy, B.; Kaladhar, K.; Anuradha, K.; Batchu, A.K.; Longvah, T.; Sarla, N. QTL Analysis for Grain Iron and Zinc Concentrations in Two, O. nivara Derived Backcross Populations. Rice Sci. 2018, 25, 197-207. [CrossRef]

73. Guerinot, M.L. Micronutrients: Supplementing seeds with zinc. Nat. Plants 2016, 2, 16060. [CrossRef]

74. Xue, W.T.; Gianinetti, A.; Wang, R.; Zhan, Z.J.; Yan, J.; Jiang, Y.; Fahima, T.; Zhao, G.; Cheng, J.P. Characterizing Barley Seed Macro- and Micro-nutrients under Multiple Environmental Conditions. Cereal Res. Commun. 2016, 44, 639-649. [CrossRef]

75. Velu, G.; Singh, R.P.; Crespo-Herrera, L.; Juliana, P.; Dreisigacker, S.; Valluru, R.; Stangoulis, J.; Sohu, V.S.; Mavi, G.S.; Mishra, V.K.; et al. Genetic dissection of grain zinc concentration in spring wheat for mainstreaming biofortifcation in CIMMYT wheat breeding. Sci. Rep. 2018, 8, 13526. [CrossRef]

76. George, T.S.; French, A.; Brown, L.K.; Karley, A.J.; White, P.; Ramsay, L.; Daniell, T. Genotypic variation in the ability of landraces and commercial cereal varieties to avoid manganese deficiency in soils with limited manganese availability: Is there a role for root-exuded phytases? Physiol. Plant. 2014, 151, 243-256. [CrossRef] [PubMed]

77. Raboy, V. Progress in Breeding Low Phytate Crops. J. Nutr. 2002, 132, 503S-505S. [CrossRef] [PubMed]

78. Brinch-Pedersen, H.; Hatzack, F.; Stöger, E.; Arcalis, E.; Pontopidan, K.; Holm, P.B. Heat-stable phytases in transgenic wheat (Triticum aestivum L.): Deposition pattern, thermostability, and phytate hydroslysis. J. Agric. Food Chem. 2006, 54, 4624-4632. [CrossRef] [PubMed]

79. Lucca, P.; Hurrell, R.; Potrykus, I. Fighting Iron Deficiency Anemia with Iron-Rich Rice. J. Am. Coll. Nutr. 2002, 21, 184S-190S [CrossRef]

80. Morris, J.; Nakata, P.A.; McConn, M.; Brock, A.; Hirschi, K.D. Increased calcium bioavailability in mice fed genetically engineered plants lacking calcium oxalate. Plant Mol. Biol. 2007, 64, 613-618. [CrossRef]

81. Tanhuanpää, P.; Kalendar, R.; Schulman, A.H.; Kiviharju, E. A major gene for grain cadmium accumulation in oat (Avena sativa L.). Genome 2007, 50, 588-594. [CrossRef] [PubMed]

82. Detterbeck, A.; Pongrac, P.; Rensch, S.; Reuscher, S.; Pečovnik, M.; Vavpetič, P.; Pelicon, P.; Holzheu, S.; Krämer, U.; Clemens, S. Spatially resolved analysis of variation in barley (Hordeum vulgare) grain micronutrient accumulation. New Phytol. 2016, 211, 1241-1254. [CrossRef] [PubMed] 
83. Pošćić, F.; Mattiello, A.; Fellet, G.; Miceli, F.; Marchiol, L. Effects of Cerium and Titanium Oxide Nanoparticles in Soil on the Nutrient Composition of Barley (Hordeum vulgare L.) Kernels. Int. J. Environ. Res. Public Health 2016, 13, 577. [CrossRef] [PubMed]

84. Moreno, J.E.; Fernández, J.M.; Puschenreiter, M.; Williams, P.N.; Plaza, C. Availability and transfer to grain of As, Cd, Cu, Ni, Pb and $\mathrm{Zn}$ in a barley agri-system: Impact of biochar, organic and mineral fertilizers. Agric. Ecosyst. Environ. 2016, 219, 171-178. [CrossRef]

85. Ishikawa, S.; Fujimaki, S. Route and Regulation of Zinc, Cadmium, and Iron Transport in Rice Plants (Oryza sativa L.) during Vegetative Growth and Grain Filling: Metal Transporters, Metal Speciation, Grain Cd Reduction and Zn and Fe Biofortification. Int. J. Mol. Sci. 2015, 16, 19111-19129.

86. Masuda, H.; Usuda, K.; Kobayashi, T.; Ishimaru, Y.; Kakei, Y.; Takahashi, M.; Higuchi, K.; Nakanishi, H.; Mori, S.; Nishizawa, N.K. Overexpression of the barley nicotianamine synthase gene HvNAS1 increases iron and zinc concentrations in rice grains. Rice 2009, 2, 155-166. [CrossRef]

87. Goto, F.; Yoshihara, T.; Shigemoto, N.; Toki, S.; Takaiwa, F. Iron fortification of rice seed by the soybean ferritin gene. Nat. Biotechnol. 1999, 17, 282-286. [CrossRef] [PubMed]

88. Ishikawa, S.; Ishimaru, Y.; Igura, M.; Kuramata, M.; Abe, T.; Senoura, T.; Hase, Y.; Arao, T.; Nishizawa, N.K.; Nakanishi, H. Ion-beam irradiation, gene identification, and marker-assisted breeding in the development of low-cadmium rice. Proc. Natl. Acad. Sci. USA 2012, 109, 19166-19171. [CrossRef]

89. Konarev, A.V.; Loskutov, I.G.; Shelenga, T.V.; Horeva, V.I.; Konarev, A.V. Plant genetic resources as an inexhaustible source of healthy food products. Agrar. Russ. 2019, 2, 38-48.

90. Ma, J.F.; Higashitani, A.; Sato, K.; Takeda, K. Genotypic variation in Fe concentration of barley grain. Soil Sci. Plant Nutr. 2004, 50, 1115-1117. [CrossRef]

91. Raj, M.S.P.; Vyakaranahal, B.S. Effect of integrated nutrient and micronutrients treatment on plant growth pa-rameters in oat cultivar (Avena sativa L.). Int. J. Plant Sci. 2014, 9, 397-400.

92. Kaur, S.; Bhardwaj, R.D.; Kapoor, R.; Greval, S.K. Biochemical characterization of oat (Avena sativa L.) genotypes with high nutritional potential. LWT Food Sci. Technol. 2019, 110, 32-39. [CrossRef]

93. Loskutov, I.G.; Rines, H.W. Avena, L. In The Book Wild Crop Relatives: Genomic and Breeding Resources, Cereals; Kole, C., Ed.; Springer-Verlag: Berlin/Heidelberg, Germany, 2011; p. 109. [CrossRef]

94. Loskutov, I.G.; Shelenga, T.V.; Konarev, A.V.; Shavarda, A.L.; Blinova, E.V.; Dzubenko, N.I. The metabolomic approach to the comparative analysis of wild and cultivated species of oats (Avena, L.). Russ. J. Genet. Appl. Res. 2017, 7, 501-508. [CrossRef]

95. Loskutov, I.G.; Shelenga, T.V.; Konarev, A.V.; Khoreva, V.I.; Shavarda, A.L.; Blinova, E.V.; Gnutikov, A.A. Biochemical aspects of interactions between fungi and plants: A case study of Fusarium in oats. Agric. Biol. 2019, 54, 575-588. [CrossRef]

96. Loskutov, I.G.; Shelenga, T.V.; Konarev, A.V.; Vargach, Y.I.; Porokhovinova, E.A.; Blinova, E.V.; Gnutikov, A.A.; Rodionov, A.V. Modern approach of structuring the variety diversity of the naked and covered forms of cultural oats (Avena sativa L.). Ecol. Genet. 2020, 18, 27-41.

97. Leonova, S.; Shelenga, T.; Hamberg, M.; Konarev, A.V.; Loskutov, I.; Carlsson, A.S. Analysis of Oil Composition in Cultivars and Wild Species of Oat (Avena sp.). J. Agric. Food Chem. 2008, 56, 7983-7991. [CrossRef]

98. Konarev, A.V.; Shelenga, T.V.; Perchuk, I.N.; Blinova, E.V.; Loskutov, I.G. Characteristic of oat diversity (genus Avena, L.) from the collection of N. I. Vavilov All-Russia Research Institute of Plants-an initial material for oat Fusarium resistance selection. Agrar. Russ. 2015, 5, 2-10.

99. Bityutskii, N.P.; Yakkonen, K.; Loskutov, I. Content of iron, zinc and manganese in grains of Triticum aestivum, Secale cereale, Hordeum vulgare and Avena sativa cultivars registered in Russia. Genet. Resour. Crop Evol. 2017, 64, 1955-1961. [CrossRef]

100. Bityutskii, N.P.; Loskutov, I.; Yakkonen, K.; Konarev, A.; Shelenga, T.; Khoreva, V.; Blinova, E.; Ryumin, A. Screening of Avena sativa cultivars for iron, zinc, manganese, protein and oil content and fatty acid composition in whole grains. Cereal Res. Commun. 2019, 48, 87-94. [CrossRef]

101. Nizova, G.K.; Yarosh, N.P. The effect of presowing seed treatment with succinic acid on the quality of oat green biomass and grain. Sci. Tech. Bull. N.I. Vavilov All Russ. Res. Inst. Plant Ind. 1988, 184, 17-20.

102. Nizova, G.K.; Rodionova, N.A. Quality of naked oat cultivars in the Northwest of the Non-Black-Earth Zone of Russia. Bull. Appl. Bot. Genet. Plant Breed. 1986, 107, 40-45.

103. Yarosh, N.P.; Nizova, G.P. Oil and fatty acid content in grain of common and Byzantine oats. Sci. Tech. Bull. N.I. Vavilov All Russ. Res. Inst. Plant Ind. 1988, 180, 18-23.

104. Yarosh, N.P.; Nizova, G.K.; Rodionova, N.A. Variability of biochemical characters in common oat cultivars depending on nature and climate zones of cultivation. Sci. Tech. Bull. N.I. Vavilov All Russ. Res. Inst. Plant Ind. 1988, 180, 3-9. 